\title{
Challenges of Bank Credit among Small and Medium Enterprises (SMEs) in Nigeria
}

\author{
JOHN N. N. UGOANI, Ph.D ${ }^{1 *}$ ONWUBIKO N. DIKE ${ }^{2}$ \\ 1. Department of Management Sciences, Rhema University, P.M.B. 7021 Aba, Abia State, Nigeria \\ 2. Department of Management Sciences, Rhema University, P.M.B. 7021 Aba, Abia State, Nigeria \\ * E-mail of the corresponding author: drjohnugoani@yahoo.com
}

\begin{abstract}
The survey research design was adopted, and the study was specifically designed to evaluate the challenges of bank-credit among SMEs in Nigeria and make recommendations. Both the questionnaire and personal interview methods were used to generate data. Data generated were coded and analyzed through tables, frequencies, percentages and Z-Test statistical technique. Bank credit refers to loans, advances and discounts (LAD) extended to borrowers for productive ventures. Nigerian Banks are still very slow in lending to SMEs. They believe that SMEs are usually not properly organized and therefore consider lending to the sector highly risky. Where they must lend, they insist on stringent loan processes including the provision of adequate collateral. These stringent loan processes frequently cut off many SMEs from having access to bank credit, and to check insider fraud, banks have placed embargo on lending without collateral. The study found that SMEs do not have significant access to bank credit in Nigeria. Ten recommendations were made based on the result of the study.
\end{abstract}

Keywords: bank credit, SMEs, NBCI, NACB, indigenization policy, NIDB, Collateral, MSMEs, SMECGS, MfBs, Liquidity, NASME, LAD, Embargo, CBN.

\section{Background:}

Bank-credit refers to loans, advances and discounts (LAD) of specified sums, terms and other conditions made available to individuals and entrepreneurs to start, grow or sustain any productive activity. Funds are necessary for the smooth running of any business, and often such funds must come in form of bank-credit. The evolution of SMEs can be traced to about 1957 when concerned political elites in parliament muted the necessity for the participation of Nigerians in some selected commercial and industrial enterpriseshitherto dominated by foreigners. Despite the agitations, not much was achieved probably because of lack of bank-credit to Nigerian entrepreneurs. In recognition of this, the Nigerian Industrial Development Bank (NIDB) was established in 1964. Another milestone in the evolution of SMEs in Nigeria was the indigenization Decree of 1972, as amended in 1977. The substance of the 1977 Indigenization Policy was to secure full participation of Nigerians in certain commercial and industrial enterprises and in some cases exclusively reserve, some small business enterprises for Nigerians, and bar aliens from specific ventures unless Nigerians have a proprietary interest of about $40 \%$. To ensure that Nigerians have access to bank-credit to promote SMEs, other specialized banks were established by government to complement the NIDB. Among them are the Nigerian Bank for Commerce and Industry (NBCI), 1973, Nigerian Agricultural and Cooperative Bank (NACB), 1973. The traditional bank LAD is normally granted for a period of one year or less and the borrower pays interest at the going interest rate. Each type of LAD has its own minimum requirements that must be met by an applicant. But banks were frequently known to be more interested in granting LAD to short-term commercial ventures that gave them more profit, to the detriment of the development of entrepreneurship in Nigeria. To give financial leverage to SMEs, the NIDB, for example, was mandated to provide medium and long-term finances to industrial enterprises ascertained to make significant contribution to economic development of the country. Also, the NBCI and the commercial banks were to create small-scale industrial departments with management capabilities to permit easy access to credit and management advice to small scale enterprises. Due to the perceived inability of these banks to meet the credit needs of SMEs, Babangida announced granting of banking licenses to new banks that would specialize and devote their resources to assist small-scale farmers and small scale industries. Among such specialized banks introduced included the Peoples Bank of Nigeria (PBN) 1989 and Community Banks (CB), 1993 (Ejiofor, 1987, Okenwa, 1999).

\subsection{Statement of the problem:}

Because of the perennial incidence of bank failure most banks in Nigeria now find it increasingly difficult to lend to SMEs. Such attitude has been reinforced due to the fact that many of the banks lack the 
requisite capital base to accommodate such lending. For example, three technically distressed banks: AfriBank, Spring Bank, and Bank PHB were nationalized in 2011 because their respective capital base were eroded due to reckless lending and insider abuses. This made the more prudent banks to resort to stringent loan processes including placing embargo on lending to certain sectors like SMEs. Some of them decided that for any loan to be approved it must go through processes as provided in their Credit Approval Manual (CAM), to reduce loan losses. Any customer that wants to borrow must make a formal request and provide all documents. The problem is that most SMEs through no fault of their own are un able to meet banks stringent lending conditions. To invert the situation, Aganga (2012) explained that the Federal Government of Nigeria (FGN) is executing marching programmes for small and medium enterprises in collaboration with the states to remove the bottlenecks associated with securing collateral and make it easier for SMEs to have access to loans to start or expand their businesses.

\subsection{Delimitation of the Study:}

This study designed to assess the challenges of bank-credit among SMEs in Nigeria was delimited to Aba because of the high concentration of such businesses in the area. Aba has the highest number of SMEs and other small and growing business enterprises (SGBEs) in South-East Nigeria. All the 300 respondents were actively engaged in various SMEs.

\subsection{Hypotheses:}

To guide the study these hypotheses were formulated and tested at 0.05 level of significance.

$\mathrm{H}_{\mathrm{O}}$ : SMEs have no significant access to bank-credit in Nigeria.

$\mathrm{H}_{1}$ : SMEs have significant access to bank-credit in Nigeria.

\section{Literature Review:}

The concept of SMEs is relative and dynamic. Its definitions vary from time to time and from one country to another. In the Central Bank of Nigeria (CBN), (1994) Circular Small Scale Enterprises were classified as those businesses with annual turnover of less than half a million naira. According to Asaze (1986) a small business is one which is owned, managed, controlled by one or two persons, is family influenced in decision-making has an undifferentiated organizational structure, has a relatively small share of the market and employs less than fifty (50) people. The National Council for Industry (NCI), (1996) defined SMEs as those, with total costs including working capital but excluding cost of land above N1 million but not exceeding N40 million, with a labour size of between 11 and 25 workers. Medium Scale Enterprises are defined as those with total costs, including capital, but excluding cost of land above N40 million but not exceeding N150 million, with a labour size of between 36 and 100 workers. SME is a global phenomenon. For example, Holland defines small scale industry as industry in which the manager personally performs all the functions of management without taking actual part in the production process. In order countries such as Napel the preamble to the Development Banks Act includes the fact that "Development Banks are connected with the development of specific sectors in order to make available financial resources and technology needed for the establishment, development, expansion and increase in the capacity and productivity of agricultural, industrial, services, trade, and productive enterprises and thus impact dynamism to the development of the nation's industrial, trade and agricultural sectors and mobilize available skills, labour and capital for the development of rural and urban areas". Despite noticeable efforts by the governments in Nigeria, including collaborating with International Organizations such as the United Nations Development Programme(UNDP), the United Nations Industrial Development Organization (UNIDO), SMEs in Nigeria still have the challenges of bank-credit. This daunting scenario led to the launching of the Microfinance Bank (MfB) Project in 2004. One of the major objectives of establishing these financial institutions and or collaborating with others is to make financial services accessible to a large segment of the potentially productive Nigerian population which otherwise would have little or no access to financial products for productive activities from the traditional or conventional Banks. SMEs as the engine for development are expected to create employment, help in skills acquisition build capacity and ultimately contribute to the growth of the Gross Domestic Product of Nigeria. For the SMEs to do this effectively, they require easy and early access to Bank-credit, even though there is evidence that the designated banks have failed to play their financing roles as expected due to inadequate financial resources available to them. When banks lack the requisite financial capacity it would be very difficult if not impossible for them to play their expected roles maximally. According to Saloko (2012) many Nigerian banks are considering raising new funds to boost their lending capacity, through debt and quasi-equity instruments given the slowdown in the equity market (UNIDO, 1969, Nweze, 2011, Aganga, 2012, Anele, 2012, Chiejina\&Adeyoye, 2012, Okonja-lweala, 2012, Adebusuyi, 2000, Naya, 1990, 
bank-credit is collateral. Banks usually require one form of collateral or the other before giving out loans. In order to facilitate SMEs access to credit the CBN launched the Agricultural Credit Guarantee Scheme (ACGS) in 1977. Guarantees are designed to remedy situations in whichborrowers with an equal probability of default have an unequal probability of obtainingcredit due to insufficient collateral. The CBN's major objective in the programme was to alleviate the problems faced by SMEs in accessing bank-credit. The scheme is meant to cover SMEs in agro and agro-allied businesses which are known to be mostly based in remote and virgin areas with large populations. Credit guarantees are conceptually designed to attract or entice reluctant lenders to advance funds to the collaterally disadvantaged sector like the SMEs, so as to achieve growth and contribute" to nation building, economic diversification and development. Guarantees also aim to improve the terms of bank-credits. (Mohammed, 2007, Jerome, 1999 Essein\&Akpan, 2007, Abumere, et al, 2002, Andrew and Jat, 1999, Olayiwole\&Busari, 2001, Pinto, et al, 1993, Webstar, 1999). In addition to the various programmes and policies, independent associations such as the Nigerian Association of Small and Medium Enterprises (NASMSE) have been formed to help SMEs in their quest for bank-credit. (Onasanya, 2012).

\section{Methodology:}

This study adopted survey research design. Both questionnaire and personal interview methods were used for data generation. The questionnaire embraced the use of five point Likert Scale format, viz, strongly agree (5 points) agree ( 4 points) neutral ( 3 points) disagree $(2$ points) and strongly disagree ( 1 point). The Yamane (1967) formula, $\mathrm{n}=\mathrm{N}$

$1+\mathrm{N}(\mathrm{e})^{2}$ where $\mathrm{n}=$ sample size, $\mathrm{N}=$ Actual population, $\mathrm{e}=$ level of significance and $\mathrm{I}-$ constant was used to derive the sample size of 300 from the strongly population of 1200 entrepreneurs in Aba (Eboh, 2009). Using systematic Linear Random Sampling Technique, the 300 respondents were selected. The questionnaire and interview questions were validated using the opinions of the professionals in academics and industry. A pilot study involving 60 entrepreneurs -respondents was conducted to determine the reliability of the research instrument using Grenache's Alpha technique. The reliability coefficient was 0.947 , indicating high degree of internal consistency of the research instrument. The data generated were filtered, organized and coded before they were classified. To analyze the data, tables, percentages and frequencies were used. $Z-T e s t$ statistical technique was applied in testing the research hypotheses. The conclusion and recommendations were made based on the findings of the study.

\section{Presentation of results}

Table 1: Sex of respondents

\begin{tabular}{|l|l|l|l|}
\hline S/N & Respondents & Responses & Percentages \\
\hline 1 & Male & 200 & 66.67 \\
\hline 2 & Female & 100 & 33.33 \\
\hline 3 & Total & 300 & $100 \%$ \\
\hline
\end{tabular}

Source: Field Work, 2012

The study used 200 male and 100 female respondents as shown in table 1.

Table 2: Collateral

\begin{tabular}{|l|l|l|l|l|}
\hline S/N & Respondents & Available & Not available & Percentages \\
\hline 1 & 62 & 62 & & 20.67 \\
\hline 2 & 238 & & 238 & 79.33 \\
\hline 3 & 300 & 62 & 238 & $100 \%$ \\
\hline
\end{tabular}

Source: Field Work, 2012

Table 2 showed that 238 or about $79.33 \%$ of the respondents had no collateral for bank-credit. 
Table 3: Financial Reports

\begin{tabular}{|l|l|l|l|l|}
\hline S/N & Respondents & Available & Not available & Percentages \\
\hline 1 & 101 & 101 & & 33.67 \\
\hline 2 & 199 & & 199 & 66.33 \\
\hline 3 & 300 & 101 & 199 & $100 \%$ \\
\hline
\end{tabular}

Source: Field Work, 2012

Table 3 revealed that 199 or $66.33 \%$ of the respondents did not keep financial reports that could facilitate bank-credit. In realization of this weakness, the National Universities Commission has made bookkeeping a compulsory course for the B.Sc. entrepreneurship degree programme.

Table 4: Membership of NASME

\begin{tabular}{|l|l|l|l|l|}
\hline S/N & Respondents & Available & Not available & Percentages \\
\hline 1 & 127 & 127 & & 42.33 \\
\hline 2 & 173 & & 173 & 57.67 \\
\hline 3 & 300 & 127 & 173 & $100 \%$ \\
\hline
\end{tabular}

Source: Field Work, 2012

In table 4 it was noted that only 127 or about $42.33 \%$ of the total respondents were registered with NASME. NASME is an umbrella that caters for the interest of SMEs.

Table 5: Analysis of Responses

\begin{tabular}{|c|c|c|c|c|c|c|c|c|c|c|}
\hline 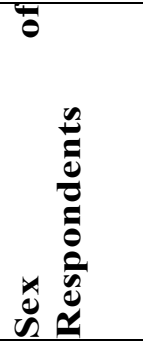 & 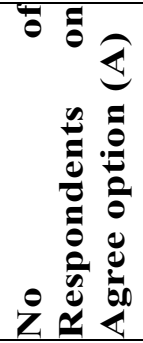 & 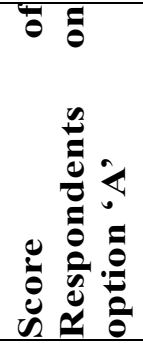 & 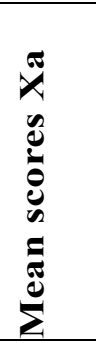 & 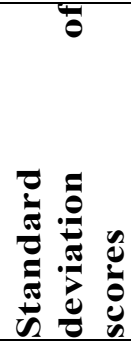 & 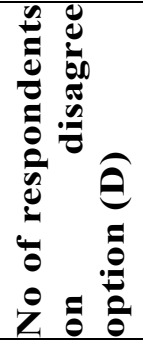 & 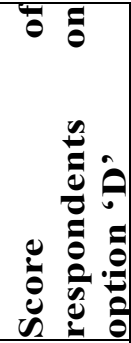 & 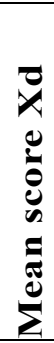 & 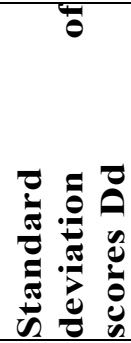 & $\stackrel{\pi}{0}$ & 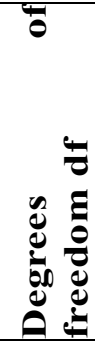 \\
\hline Male & 25 & 84 & 3.36 & 13.78 & 75 & 129 & $\begin{array}{l}1 . \\
7 \\
2\end{array}$ & 5.99 & 100 & \\
\hline Female & 65 & 219 & 3.34 & 8.44 & 135 & 232 & $\begin{array}{l}1 . \\
7 \\
0\end{array}$ & 4.45 & 200 & \\
\hline Total & 90 & 303 & 6.70 & 22.22 & 210 & 361 & $\begin{array}{l}3 . \\
4 \\
2\end{array}$ & 10.44 & 300 & $\stackrel{7}{n^{\prime}}$ \\
\hline $\begin{array}{l}\text { Averag } \\
\text { e }\end{array}$ & 45 & 151.5 & 3.35 & 11.11 & 105 & 180.5 & $\begin{array}{l}1 . \\
7 \\
1\end{array}$ & 5.22 & 150 & 4 \\
\hline
\end{tabular}

Source: Field Work, 2012

Table 5 showed that at out of 300 respondents 90 , representing about 30 percent agreed that SMEs have access to bank credit while 210 or about 70 percent are differed in this opinion. 


\begin{tabular}{|c|c|c|c|c|c|c|c|c|}
\hline 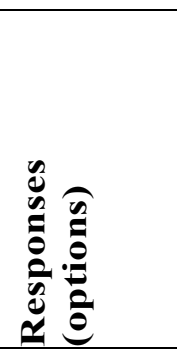 & 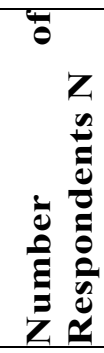 & 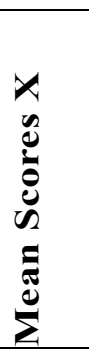 & 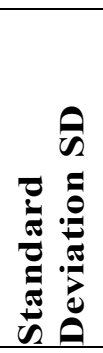 & 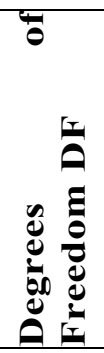 & 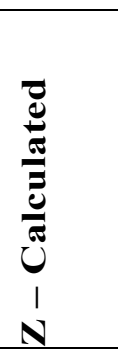 & 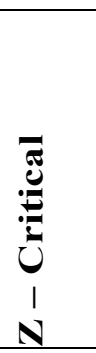 & 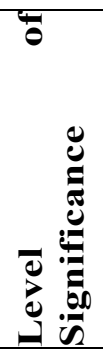 & 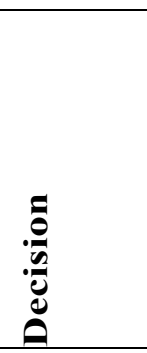 \\
\hline Agree & 90 & 3.35 & 3.36 & & & & & \\
\hline Disagree & 210 & 1.71 & 5.22 & 4 & +0.76 & $\begin{array}{l}+1.9 \\
6\end{array}$ & 0.05 & $\begin{array}{l}\text { Accept } \\
\text { ed }\end{array}$ \\
\hline
\end{tabular}

Source: Field Work, 2012

From table 6 , the calculated $\mathrm{Z}$ - value $(+0.76)$ was found in the region between -1.96 and +1.96 (ie critical values of $Z$ ) at 4 degrees of freedom and 0.05 level of significance. The null hypothesis, Ho was not rejected. . The P-value provided additional insight into the decision. The probability of finding a Z-value as extreme as +0.76 was $0.5000-0.2764=0.2236$. The two tailed P-value, $2(0.2236)=0.4472$, was greater than the significance level of 0.05 (ie $\mathrm{P}>0.05$ ). The null hypothesis therefore was true and could not be rejected, confirming that SMEs do not have significant access to bank credit in Nigeria. With this empirical result it was found that SMEs in Nigeria do not have significant access to bank-credit. This empirical result supports the notion in many quarters that SMEs are starved of bank-credit in Nigeria. This is despite the launching of several special banks and schemes in the past. In fact it is widely believed that banks are killing businesses in Nigeria. For example, Nweze, (2011) quoted Central Bank of Nigeria statistics to show that while aggregate credit to the public sector grew by 67.83 percent in 2010, credit to the private sector including SMEs, dropped by 4.92 percent in the same period. In order to address the ugly situation, the Federal Government of Nigeria, through the $\mathrm{CBN}$, is concluding arrangements for the launching of Micro, Small and Medium Enterprises (MSMEs) development fund scheme as well as a N200 billion Small and Medium Enterprises Credit Guarantee Scheme (SMCGS). According to Nweze (2012) the MSME development fund will provide liquidity support for the Microfinance Banks (MfBs) to reduce the twine problems of liquidity among the MfBs. This is in realization of the fact that one reason for the mass liquidation of $103 \mathrm{MfBs}$ in 2010 was lack of liquidity which did not give them the capacity to perform their lending roles effectively. The result of this study is not an exaggeration since it also supports the opinion of Gills-Harry (2012) that Nigerian banks are still very slow in supporting businesses but only know how to keep and charge high transaction costs, this is discouraging. Nigeria at present has about $17.3 \mathrm{~m}$ SMEs and if they are supported with bank-credit they could be creating about 8 million jobs each year to reduce youthunemployment that is as highas 67 million in Nigeria.(Osehobo, 2012). The analysis in table 4 showed that only 127 or about $42.33 \%$ of the total respondents patronize the National Association of Small and Medium Enterprises of Nigeria. As much as 173 respondents or about $57.67 \%$ were yet to register with them. Not being a member of such a high profile pressure group could be detrimental to the growth and productivity of any small and medium scale enterprise. Such business groups were established on the understanding that the development of small and medium scale enterprises is a necessary requirement for the economic transformation of the nation.

\subsection{Scope for further Research}

Further research should focus on the need for capital adequacy for banks to see if it will ameliorate credit challenges among SMEs in Nigeria.

\subsection{Recommendations:}

Based on the findings of this research, which was conducted in Aba, Abia State, Nigeria, the following recommendations were made.

1. Banks should be made to yield to Federal Government's directives of extending the required credit to small and medium scale enterprises in Nigeria. This will help in economic development of the country. 
2. Small and Medium Enterprises should not rely too much on personal finance as that would not give room for expansion of the enterprises. They should exhaust the chances of Bank-credit, by keeping good financial reports.

3. Small and Medium Scale Enterprises promoters should avoid the fusion of ownership with management to avoid the collapse of the business in their personal absence; or even death, this will help in reducing unemployment.

4. The influence of family members should be reduced in small and medium enterprises to ensure the benefit of expertise and sound management.

5. The use of inexperienced personnel is dangerous because not only that they are not competent, they may not appreciate the need for the growth of the enterprises beyond the micro level.

6. The CBN should raise the penalty on banks for failing to lend the required quota of their total loans, advances, and discounts (LAD) to small and medium enterprises. This will help in enforcing compliance.

7. Small and Medium Enterprises should ensure to have the legal title over their landed properties which they can use to cover bankcredit as collateral.

8. Banks should make credit terms for SMEs as simple as possible to help them in their quest for facilities, bearing in mind the educational background of an average small business holder in Nigeria.

9. Small and Medium Scale Enterprises should patronize business groups available to them. This will enable them get proper information and assistance towards securing bank-credit.

10. Because of the central importance of small and medium scale enterprises to the transformation of the economy, the Government should make it mandatory for all of them to join the relevant business groups. To achieve this, mode of entry should be regulated and simplified by the appropriate government agency.

\section{Conclusion}

It is hoped that the problems of small and medium scale enterprises can be minimized if the recommendations of this research are implemented. Small and medium Scale Enterprises should always take necessary steps so as to enable them enjoy bank-credit facilities. Nigeria needs the growth of these enterprises for its rapid economic transformation. A major role of banks in any economy is sound financial intermediation. Not granting the stipulated quota of credit to the small and medium scale enterprises should be viewed by government as an act of economic sabotage which should attract appropriate sanctions. The one-man "syndrome" and "family affairs" mentality in small and medium scale enterprises should be reduced to manageable proportions. Small and medium scale enterprises should employ competent managers and minimize the use of unskilled manpower. They should keep proper accounting records that would help them to be assessed by any external body. Membership of business groups is necessary because they stand to benefit a great deal in terms of sources of cheap funds, advice and collaboration with the macro environment. This study found that SMEs do not have significant access to bank-credit in Nigeria.

\section{References:}

[1] Adamu, B. I. (2005), Small Medium Industries Equity Investment Scheme SMEIS: Pro or anti-industrialization CNB Bullion, Oct./Dec. 2005, Vol. 29, No. 04.

[2] Aganga, O. (2012, Nigeria has about 17.3m SMEs. The Nation Vol. 7, No. 2143.Pp. 12.

[3] Andrew, J. O. M. and Jat, R. B. (1999), Problems of Financing Small and Medium Size Business by Banks, First Bank of Nigeria Bi-Annual Review, Dec. 1999, Vol. 7, No. 15.

[4] Anele, J, (2012) Diamond Bank Grooms Entrepreneurs. The Nation, Vol. 6, No. 2068.Pp. 58.

[5] Akinboyo, O. L. (2007), Microfinance Bank: Unlocking the Potentials of Micro-business activities of the Nigerian Rural Economy, Central Bank of Nigeria Bullon, Jan./March, 2007, Vol. 31, No. 1.

[6] Abumere, S. I., Aigbokhan, B. E. and Mabawonku, A. O. (2002), Building the Nigerian Private Sector 38, Ibadan.

[7] CBN (1994) Guidelines for Finance Companies. Abuja.

[8] Chiejina, N, and Adeyeye, A, (2012) Microfinance Banks to Face Stress Testbefore assessing funds. The Nation, Vol. 7, No. 2185.Pp. 11.

[9] Adebusuyi, B. S (2000) "Development of Small and Medium Enterprises in Nigeria" Central Bank of Nigeria: Economic and Financial Review. Abuja. 
[10] Ebo E. C. (2009) Social and Economic Research Principles and Methods. $2^{\text {nd }}$ Edition, Enugu, African Institute for Applied Economics.

[11] Ejiofor, P. N. O. (1987), Management in Nigeria, Theories and Issues, Onitsha, Africana-FEB Publishers Limited.

[12] Essien, S. N. and Akpan, N. I. (2007) Credit and Private Sector Investment in Nigeria, Central Bank of Nigeria Bullon, Vol. 31, No. 1.

[13] Gillis-Hary, B, (2012) Banks are killing Businesses. The Nation, Vol. 7, No. 2182, pp. 32 - 33.

[14] Jerosme, A, (1999) "Unleashing the Private Sector in Nigeria, "Afribank Economic and Financial Review, Vol. 1, No. 1, pp. 1-20.

[15] Ledgerwood, J, and White, V, (2006). Transforming Microfinance Institutions, Washington, D. C.The World Bank.

[16] Mohammed, S. E. (2007), Establishing a Credible Small and Medium Enterprises (SMEs) Credit Guarantee Scheme in Nigeria. Lessons from the Operations of the Agricultural Credit Guarantee Scheme (ACGS).

[17] Naya, S, (1990), Private Sector Development and Enterprises Reforms in Growing Asian Economies" An International Center for Economic growth Publication ICS Press, San Fransisco, Califonia.

[18] National Council for Industries (1996) Guidelines, Abuja.

[19] National Universities Commission (2011) Benchmark Minimum Academic Standards for Undergraduates Programmes in Nigerian Universities.

[20] Nweze, C, (2011) Banks Place Embargo on Temporary overdrafts. The Nation, Vol. 6, No. 1665, pp. 29. , (2012) Microfinance Fund to address sector hitches. The Nation, Vol. 7, No. 2085, pp. 55

[22] Nzenwa, S. O. E. (2000) Microcredit and Development in Nigeria. Lagos, Mbeyi\& Associates Nigeria Ltd.

[23] Okenwa C. P. (1999) Entrepreneurship Development in Nigeria, Onitsha Adson Educational Publishers.

[24] Okonjo-Iweala N, (2012) Okonjo-Iweala seeks Diversification of Economy. The Nation, Vol. 7, No. 2185, pp. 11.

[25] Olayiwola, K. and Busari, D. T. (2001) "Economic Reforms Programme and Private Sector Development in Nigeria Development Policy Center Research Report No. 35, Ibadan, Nigeria.

[26] Onasanya, B. (2012) Firstbank, NASSI sign MoU on Loan Schemes. The Nation, Friday, June 15, 2012, Vol. 7. No. 2157.pp. 4.

[27] Osaze, B. E. (1986) Developing Small Scale Industries in Nigeria. Business Times, February, 17,

[28] Osehobo, V, (2012) 67 Million Youths unemployed - Minister. Nigerian Pilot. Vol. 2, No. 154, pp. 1-2.

[29] Ugoani, J. N. N. (2013) Effect of Emotional Intelligence on Bank Success. Germany, Lambert Academic Publishing.

[30] ........., (2006) Manpower Challenges in the banking Sector: A Nigerian Perspective. Managing Business in Nigerian Journal Vol. 5, No. 3, Owerri Motivators Consult.

[31] ..........., (1998) Minimizing Distress in the Nigerian banking System. The Prospective Accountant.AkanuIbiam Federal Polytechnic UwanaAfikpo Vol. 2, No. 190, Nigeria.

[32] United Nations Industrial Development Organization (UNIDO) Small Scale Industry. Industrialization of Developing Countries, Problems and Prospects, New York, UNIDO, 1969.

[33] Pinto, B. M. Becka, and Krajewoski (1993), "Transforming State Enterprises in Poland: Evidence on Adjustment by Manufacturing Firms" Brookings Papers, Economic Activity. Pp. 213 - 261.

[34] Saloko, T, (2012) Banks to Source Capital to boost Capacity. The Nation, Vol. 7, No. 2085.Pp. 55.

[35] Webster, L. (1999), "SMEs in Vietnam: On TheRoad to Prosperity, "Private Sector Discussions, MPDF, Hanoi. 
This academic article was published by The International Institute for Science, Technology and Education (IISTE). The IISTE is a pioneer in the Open Access Publishing service based in the U.S. and Europe. The aim of the institute is Accelerating Global Knowledge Sharing.

More information about the publisher can be found in the IISTE's homepage: http://www.iiste.org

\section{CALL FOR PAPERS}

The IISTE is currently hosting more than 30 peer-reviewed academic journals and collaborating with academic institutions around the world. There's no deadline for submission. Prospective authors of IISTE journals can find the submission instruction on the following page: http://www.iiste.org/Journals/

The IISTE editorial team promises to the review and publish all the qualified submissions in a fast manner. All the journals articles are available online to the readers all over the world without financial, legal, or technical barriers other than those inseparable from gaining access to the internet itself. Printed version of the journals is also available upon request of readers and authors.

\section{IISTE Knowledge Sharing Partners}

EBSCO, Index Copernicus, Ulrich's Periodicals Directory, JournalTOCS, PKP Open Archives Harvester, Bielefeld Academic Search Engine, Elektronische Zeitschriftenbibliothek EZB, Open J-Gate, OCLC WorldCat, Universe Digtial Library, NewJour, Google Scholar

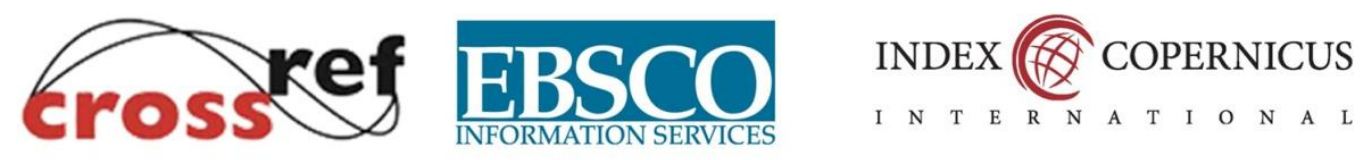

(O) ULRICHSWEB"

JournalTOCs

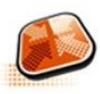

PKP | PUBLIC KNOWLEDGE PROJECT
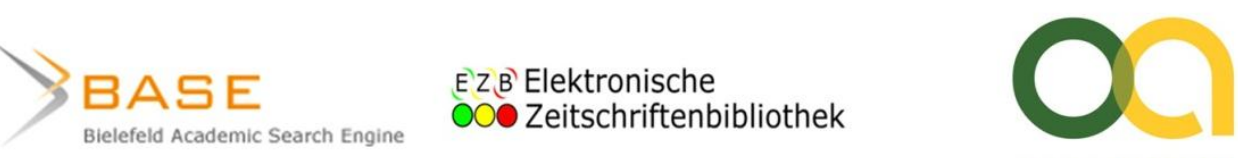

open access
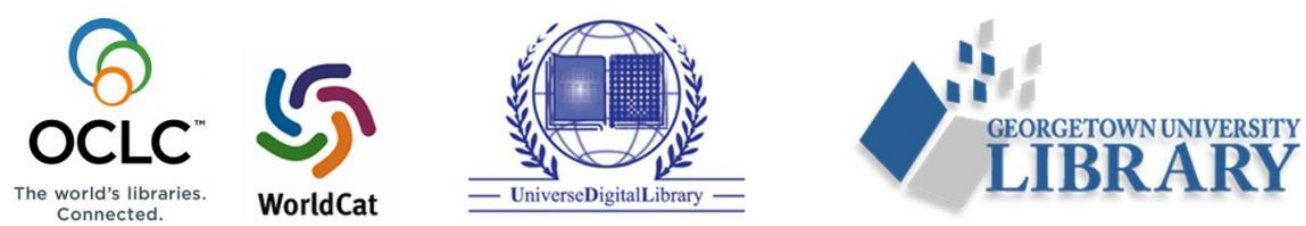